\title{
Pengaruh Kebiasaan Belajar Daring terhadap Hasil Belajar Kognitif Siswa pada Mata Pelajaran Bahasa Indonesia Kelas XII IPA di SMA N Kerinci
}

\author{
Indratno \\ Guru SMAN 7 Kerinci \\ Correspondence email: Indratno710211@gmail.com
}

\begin{abstract}
Abstrak. Tujuan penelitian ini adalah untuk mengetahui pengaruh kebiasaan belajar daring dengan hasil belajar kognitif siswa pada mata pelajaran bahasa Indonesia kelas XII IPA di SMA Negeri 7 Kerinci. Penelitian ini ini menggunakan metode penelitian kuantitatif dengan pendekatan asosiatif. . Populasi dalam penelitian ini sebanyak 97 siswa dan diambil beberapa sampel melalui teknik pengambilan sampel dengan menggunakan simple random sampling, dimana pengambilan sampel tiap kelas ditentukan seimbang atau sebanding dengan banyaknya subjek dari setiap kelas. Untuk menghitung sampel penelitian dari populasi tersebut, peneliti menggunakan pedoman penentuan sampel yang dikembangkan dari Isaac dan Michael dengan taraf tingkat kesalahan 5\% sehingga sampel dalam penelitian ini sebanyak 32 siswa. Instrumen angket kebiasaan belajar daring (X) penelitian ini menggunakan skala likert untuk mengukurnya, dan hasil belajar kognitif beardasarkan hasil belajar ujian berupa pengetahuan pembelajaran pada pembelajaran bahasa Indonesia. Selanjutnya dilakukan uji validitas dan reliabilitas dari angket tersebut untuk mengumpulkan data. Setelah data terkumpul dilakukan uji analisis deskriptif, uji normalitas, uji homogenitas, uji hipotesis dengan menggunakan uji regresi sederhana dan uji t. Hasil penelitian ini bahwa terdapat pengaruh kebiasaan belajar daring terhadap hasil belajar kognitif siswa kelas XII IPA SMA Negeri 7 Kerinci ditandai dengan nilai $t$ hitung $>t$ tabel dan siginifikansi $0,040<0,05$. Besarnya pengaruh kebiasaan belajar daring terhadap hasil belajar bahasa Indonesia siswa kelas XII IPA SMA Negeri 7 Kerinci tergolong kuat yaitu sejumlah $51 \%$ dengan sisa $49 \%$ dipengaruhi oleh faktor lain di luar penelitian.
\end{abstract}

Kata Kunci: Kebiasaan Belajar Daring, Hasil Belajar Kognitif

Abstract. The purpose of this study was to determine the relationship between online study habits and student cognitive learning outcomes in Indonesian class XII IPA SMA Negeri 7 Kerinci. This study uses quantitative research methods with an associative approach. The population in this study was 97 students and several samples were taken through a sampling technique using simple random sampling, where the sampling of each class was determined to be balanced or proportional to the number of subjects from each class. To calculate the research sample from the population, the researcher used the sampling guideline developed by Isaac and Michael with an error rate of 5\% so that the sample in this study was 32 students. The online study habits questionnaire instrument $(X)$ uses a Likert scale to measure it, and cognitive learning outcomes are based on test learning outcomes in the form of learning knowledge in Indonesian language learning. Furthermore, the validity and reliability of the questionnaire was tested to collect data. After the data was collected, a descriptive analysis test, normality test, homogeneity test, hypothesis testing was carried out using a simple regression test and t test. The results of this study indicate that there is an influence of online learning habits on cognitive learning outcomes of students of class XII IPA SMA Negeri 7 Kerinci marked by the value of $t$ count $>t$ table and a significance of $0.040<0.05$. The magnitude of the influence of online study habits on Indonesian language learning outcomes for students of class XII IPA SMA Negeri 7 Kerinci is quite strong, namely 51\% with the remaining $49 \%$ influenced by other factors outside the study.

Key words: Daring Study Habits, Cognitive Learning Outcomes

\section{PENDAHULUAN}

Sudah hampir dua tahun virus covid 19 melanda negeri yang kita cintai ini, banyak dampak yang terkena akibat virus tersebut hampir diseluruh bidang kehidupan manusia salah satunya bidang pendidikan. Pendidikan amat penting bagi manusia karena selama manusia hidup akan terus beraktivitas untuk terus belajar dan belajar. Pada dasarnya belajar itu bagian dari pendidikan, dimana di dalam proses belajar terdapat suatu kegiatan pokok utama dalam dunia pendidikan. Manusia tidak akan pernah berhenti belajar karena setiap langkah manusia dalam hidupnya akan dihadapkan pada permasalahan yang membutuhkan pemecahan dan menuntut manusia untuk belajar menghadapinya. Banyak permasalahan yang dihadapi siswa dan guru dari adanya virus covid 19 ini dalam melakukan proses pembelajaran salah satunya adalah proses 
Indratano, Pengaruh Kebiasaan Belajar Daring terhadap Hasil Belajar Kognitif Siswa pada Mata Pelajaran Bahasa Indonesia Kelas XII IPA di SMA N Kerinci

pembelajaran tidak bisa dilakukan secara tatap muka lagi, siswa dan guru harus membiasakan diri melakukan pembelajaran melalui proses daring atau internet learning.

Adapun keseluruhan proses pendidikan saat ini yang dilakukan secara daring membuat tugas guru tidak hanya mentransfer ilmu pengetahuan saja, tetapi juga harus mengajarkan siswa dalam menerapkan teknologi dengan membiasakan belajar melalui daring. Selain itu, tidak menjadikan siswa sebagai objek pembelajaran melainkan sebagai subjek pembelajaran, sehingga siswa tidak pasif dan dapat mengembangkan pengetahuan yang dimilikinya sesuai dengan bidang studi yang dipelajari. Proses tersebut bagian dari kegiatan pembelajaran yang merupakan komponen pendidikan yang penting. Dalam kegiatan tersebut melibatkan siswa dan guru yang saling bekerjasama dalam mewujudkan situasi kondisi pembelajaran yang efektif dan efesien agar apa yang menjadi tujuan pembelajaran dan standar kompetensi dapat tercapai. Untuk mencapai tujuan pembelajaran dan standar kompetensi banyak factor yang mempengaruhinya salah satunya adalah kebiasaan belajar. Kebiasaan belajar dapat didefinisikan sebagai cara atau teknik yang menetap pada diri siswa pada waktu menerima pelajaran, membaca buku, mengerjakan tugas, dan pengaturan waktu untuk menyelesaikan kegiatan (Djaali, 2014:128).

Pengaturan waktu dan perencanaan kegiatan untuk membiasakan siswa dalam belajar harus dilakukan siswa secara berulang-ulang setiap harinya agar bisa mempersiapkan diri dalam mengikuti pembelajaran. Kegiatan yang dilakukan berulang-ulang inilah yang disebut dengan kebiasaan belajar. Bila dilihat dari aspek psikologis belajar merupakan suatu proses perubahan tingkah laku sebagai hasil dari interaksi dengan lingkungan dalam memenuhi kebutuhan hidupnya. Slameto (2015:2) berpendapat bahwa belajar ialah proses usaha yang dilakukan seseorang untuk suatu perubahan tingkah laku yang baru secara keseluruhan, sebagai hasil pengalamannya sendiri dalam interaksi dengan lingkungannya. Perubahan tersebut semuanya akan nyata dalam seluruh aspek tingkah laku yakni baik dari sisi aspek kognitif, afektif dan psikomotorik. Oleh karena itu banyak hal yang harus dilakukan guru dalam mewujudkan hasil belajar tersebut diantaranya guru harus memperhatikan penampilan, tingkah laku dan kepribadian. Selain itu juga guru harus menguasai materi, memilih model pembelajaran yang tepat, penggunaan bahasa yang mudah dipahami, manajemen kelas yang baik dan masih banyak lagi yang kesemua itu dimaksudkan untuk dapat memberikan motivasi berprestasi dan menjadikan kebiasaan untuk selalu belajar sebagai bagian terpenting dalam diri siswa.

Pencapaian prestasi yang tinggi dipengaruhi oleh banyak faktor.Sebagaimana yang diungkapkan oleh Slameto (2015:54-72) faktor-faktor yang mempengaruhi hasil belajar digolongkan menjadi dua golongan diantaranya faktor intern yaitu faktor yang berasal dari dalam individu dan faktor ekstern yang berasal dari luar individu. Salah satu faktor intern yang mempengaruhi hasil belajar ialah kebiasaan belajar.

Hasil belajar pada dasarnya dipengaruhi oleh banyak faktor yang saling terkait, baik yang berasal dari dalam maupun dari luar, dengan demikian pada hakekatnya tidak ada faktor tunggal yang dapat berdiri sendiri menentukan hasil belajar seseorang. Hasil Belajar adalah perubahan yang mengakibatkan manusia berubah dalam sikap dan tingkah lakunya (Winkel dalam Purwanto, 2016:4). Beberapa masalah yang terkait dengan hasil belajar seseorang anatara lain motivasi berprestasi siswa dan kebiasaan belajar siswa. Kemampuan belajar yang dimiliki seseorang pada umumnya merupakan sesuatu yang dapat dijadikan bekal pokok, karena melalui belajar seseorang dapat menambah dan mengembangkan sikap dirinya untuk dapat menjadi lebih baik lagi. Kebiasaan seseorang dengan orang lain berbeda, tergantung dari pribadi individu itu sendiri. Ada yang sudah memiliki kebiasaan yang baik dalam belajar, dan juga yang belum memiliki kebiasaan yang baik dalam belajar tetapi mereka tidak merubah kebiasaan itu atau terus melakukan kebiasaan buruk tersebut.

Saat ini pembelajaran tatap muka antara guru siswa dibatasi akibat adanya virus covid 19, sehingga proses pembelajaran dilakukan secara daring. Hal ini, membuat siswa harus mengubah kebiasaan belajar yang semula tatap muka menjadi pembelajaran daring. Akan tetapi berdasarkan observasi penelitian pada saat melakukan proses pembelajaran pada mata pelajaran bahasa Indonesia pembelajaran tatap muka tidak cukup membahas satu materi pelajaran. Hal ini ditandai dengan banyaknya waktu tatap muka pembelajaran yang terpotong karena adanya libur hari besar, ujian nasional kelas XII, agenda kegiatan sekolah dan kegiatan sekolah diadakan sampai hari jumat atau fullday school sehingga membuat guru untuk mengejar 
Indratano, Pengaruh Kebiasaan Belajar Daring terhadap Hasil Belajar Kognitif Siswa pada Mata Pelajaran Bahasa Indonesia Kelas XII IPA di SMA N Kerinci

materi yang tertinggal. Pada akhirnya ada beberapa materi yang belum disampaikan akibat tatap muka yang dilakukan guru dan peserta didik yang terpotong dan pada akhirnya peserta didik merasa belum mampu atau belum mengerti dengan materi yang diajarkan karena pada saat dijelaskan guru terpaku dengan waktu. Jika hanya mengandalkan pembelajaran tatap muka di kelas tentu tidak efisien dan efektif, karena siswa harus berkonsultasi dengan guru untuk membahas materi tersebut tidak sekedar mencatat dan memfotocopy file. Untuk mencapai tujuan dari pembelajaran bahasa Indonesia kelas XII SMA Negeri 7 Kerinci dalam proses pembelajaranya tidak hanya dilakukan secara tatap muka, juga bisa dilakukan secara daring. Hal ini perlu dibiasakan,karena kebiasaan belajar secara daring dapat dilakukan kapanpun dan dimanapun siswa dapat belajar dan menanyakan hal-hal yang kurang dimengerti dari pembelajaran tersebut. Pembelajaran bahasa Indonesia di sekolah tidak cukup hanya dengan sebuah materi yang diberikan kepada siswa tetapi juga harus memberikan pengalaman atau kehidupan nyata kepada siswa untuk memahami materi yang diberikan.

Hasil pembelajaran dikatakan berkualitas apabila pembelajaran yang dilaksanakan dapat memberi kemampuan, pengetahuan, dan keterampilan pada lulusannya yang berguna untuk melanjutkan pendidikan yang lebih tinggi ataupun memasuki dunia kerja. Pembaruan dan pengembangan pembelajaran sangat diperlukan untuk menciptakan pembelajaran berkualitas yang sesuai dengan kebutuhan siswa saat ini. Hal ini akan tercapai apabila proses belajar mengajar dilaksanakan secara efektif sehingga hasil pembelajaran bisa optimal. Pentingnya mengetahui hasil belajar siswa yaitu untuk mengetahui seberapa jauh siswa dapat menguasai dan memahami materi dari mata pelajaran yang telah diajarkan guru di selama proses pembelajaran yang dibiasakan secara daring tersebut. Hasil belajar yang baik merupakan harapan dari semua pihak baik dari siswa sendiri, guru, orang tua, dan sekolah.

Keberhasilan siswa di sekolah tidak luput ditandai dengan adanya perubahan kebiasaan belajar pada diri individu siswa tersebut. Kebiasaan belajar merupakan salah satu faktor yang mempengaruhi prestasi belajar siswa. Siswa yang memiliki kebiasaan belajar teratur dalam kesehariannya, akan memiliki kemampuan untuk berprestasi lebih baik dari pada siswa yang memiliki kebiasaan belajar yang kurang teratur dan hanya belajar pada saat menjelang ujian tiba. Siswa yang rajin belajar dan mempunyai kebiasaan belajar yang baik, maka dalam pencapaian prestasi belajar akan bisa diraih semaksimal mungkin, karena siswa tersebut mempunyai persiapan yang matang diwaktu ujian semester ataupun ujian nasional. Berbeda dengan siswa yang tidak mempunyai rutinitas belajar apabila akan menghadapi ujian siswa tersebut akan belajar lembur.

Pada pembelajaran bahasa Indonesia dibutuhkan kebiasaan belajar sebagai dasar untuk dapat memahami konsep-konsep dalam berbahasa terutama banyak hafalan, hal tersebut dipengaruhi oleh metode pembelajaran yang digunakan agar dapat meningkatkan hasil belajar bahasa Indonesia. Oleh karena itu, dalam proses pembelajaran siswa dituntut untuk aktif dan membiasakan diri untuk selalu mengulang pelajaran yang telah di ajarkan dan berusaha belajar mandiri sebagai pengetahuan awal siswa sehingga daya ingat siswa memahami konsep terhadap apa yang dipelajari akan lebih baik, dengan kebiasaan belajar setiap hari serta adanya motivasi berprestasi dari dalam diri sendiri maka hasil belajar pun akan menjaadi lebih baik. Berdasarkan permasalahan yang telah dipaparkan tersebut, penelitian ini bertujuan untuk mengetahui tentang pengaruh kebiasaan belajar daring dengan hasil belajar kognitif siswa pada mata pelajaran bahasa Indonesia kelas XII di SMA Negeri 7 Kerinci.

\section{LANDASAN TEORI}

\section{Kebiasaaan Belajar Daring}

Tindakan belajar yang berasal dari diri siswa bersamaan dengan proses belajar yang dilakukan siswa tersebut, karena siswa mempelajari dan mengamati dari lingkungan di sekitar mereka, bukan berasal dari bakat yang telah dipunyai siswa sejak kecil bisa disebut dengan kebiasaan belajar. Lewat proses belajar tersebut akan terbentuk kebiasaan belajar siswa secara sadar maupun tidak dan proses tersebut berlangsung secara terus menerus. Proses belajar tersebut dilaksanakan siswa ketika berada di rumah maupun di sekolah. Hal tersebut dilakukan oleh siswa untuk memperoleh hasil belajar yang memuaskan, seperti yang dikatakan Syah (2009:128) bahwa kebiasaan belajar adalah proses pembentukan kebiasaan-kebiasaan baru atau 
Indratano, Pengaruh Kebiasaan Belajar Daring terhadap Hasil Belajar Kognitif Siswa pada Mata Pelajaran Bahasa Indonesia Kelas XII IPA di SMA N Kerinci

perbaikan kebiasaan yang telah ada. Tujuannya agar siswa memperoleh sikapsikap dan kebiasaan-kebiasaan perbuatan baru yang lebih tepat dan positif dalam arti selaras dengan kebutuhan ruang dan waktu. Slameto (2015:82), menyatakan bahwa kebiasaan belajar bertujuan untuk mendapatkan pengetahuan, sikap, kecaka pan, dan keterampilan, cara-cara yang dipakai itu akan menjadi kebiasaan.

Menurut Gilmer (1996:12) mengungkapkan bahwa kebiasaan belajar itu sebagai habit a well learned response carried out outomatically. Sedangkan Aunurrahman (2013: 185) berpendapat bahwa kebiasaan belajar merupakan tingkah laku belajar seseorang yang sudah tertanam dalam jangka waktu yang relatif lama sehingga memberikan karakteristik dalam aktivitas belajar yang dilakukannya. Lebih lanjut Djaali (2014:128) menerangkan tentang kebiasaan belajar itu merupakan faktor yang mempengaruhi hasil belajar siswa. Siswa yang mempunyai kebiasaan belajar teratur, terarah, dan runtut dalam kesehariannya, akan memiliki kemampuan untuk merai prestasi atau hasil bbelajar yang lebih baik dari pada siswa yang mempunyai kebiasaan belajar yang kurang teratur dan hanya belajar pada saat menjelang waktu ujian tiba. Siswa yang rajin belajar dan mempunyai kebiasaan belajar yang baik maka dalam pencapaian prestasi belajar akan bisa diraih semaksimal mungkin, karena siswa tersebut mempunyai persiapan yang matang di waktu ujian maupun pada saat pembelajaran di kelas. Djaali (2014:129) mengelompokan kebiasaan belajar menjadi dua bagian yaitu:

1)Delay Avoidance menunjuk pada ketepatan waktu penyelesaian tugas-tugas akademis, menghindarkan diri dari hal-hal yang memungkinkan tertundanya penyelesaian tugas, dan menghilangkan rangsangan yang akan mengganggu konsentrasi dalam belajar.

2) Work Methodes menunjuk pada penggunaan cara (prosedur) belajar yang efektif, dan efisiensi dalam mengerjakan tugas akademik dan keterampilan belajar.

Masih menurut Djali (2014:129) ada terdapat sepuluh indicator dalam mengukur kebiasaan belajar daring diantaranya adalah (1) cara mengikuti pelajaran (2) cara belajar kelompok (3) cara belajar individu (4) mempelajari buku teks (5) pembuatan jadwal dan pelaksanaanya (6) membaca dan membuat catatan (7) mengulangi bahan pelajaran (8) menghadapi ujian (9) konsentrasi (10) mengerjakan tugas. Lebih lanjut Ardiansyah (2012) menjelaskan bahwa kebiasaan belajar adalah keteraturan berperilaku yang otomatis dalam belajar yang dapat dilihat dan diukur dari keseringan atau frekwensi melakukan kegiatan yang merupakan kebiasaan-kebiasaan belajar yang baik dengan ditunjukkan melalui indikator-indikator berikut: a) Mempersiapkan diri dalam mengikuti pelajaran; b) Memantapkan materi pelajaran; c) Menghadapi tes. Sedangkan menurut pendapat Gie (1995:193) kebiasaan belajar didefinisikan sebagai suatu perilaku yang ditunjukan secara tetap atau kontinu dari waktu ke waktu dalam rangka pelaksanaan belajar. Sedangkan menurut Sudjana (2014:165) ada beberapa hal yang menjadi indicator dalam kebiasaan belajar diantaranya hal yang perlu diperhatikan dalam proses belajar, yaitu: a) Cara mengikuti pelajaran, b) Cara belajar mandiri di rumah, c) Cara belajar kelompok, d) Mempelajari buku teks, dan e) Menghadapi ujian."

Kebiasaan belajar terdapat dua bagian yaitu kebiasaan belajar yang baik dan kebiasaan belajar yang buruk, berikut paparanya menurut Gie (1995:194):

1) Kebiasan belajar yang baik ditunjukan dengan perilaku melakukan studi secara teratur setiap hari, mempersiapkan semua keperluan studi pada malamnya sebelum keesokan harinya berangkat, senantiasa hadir dikelas sebelum pelajaran dimulai, terbiasa belajar sampai paham betul dan bahkan tuntas tak terlupakan lagi, terbiasa mengunjungi perpustakaan untuk menambah bacaan atau menengok buku referensi mencari arti-arti istilah

2) Kebiasaan belajar buruk ditunjukan dengan perilaku hanya melakukan studi secara mati-matian setelah ujian di ambang pintu, sesaat sebelumnya berangkat barulah ribut mengumpulkan buku dan peralatan yang perlu dibawa, sering terlambat hadir, umumnya belajar seperlunya saja sehingga butir-butir pengetahuan masih kabur dan banyak terlupakan, dan jarang sekali masuk perpustakaan dan tidak tahu caranya mempergunakan ensiklopedi dan berbagai karya acuan lainnya.

\section{Hasil Belajar Kognitif}


Indratano, Pengaruh Kebiasaan Belajar Daring terhadap Hasil Belajar Kognitif Siswa pada Mata Pelajaran Bahasa Indonesia Kelas XII IPA di SMA N Kerinci

Definisi hasil belajar merujuk pada suatu perolehan akibat dilakukannya suatu aktivitas atau proses yang mengakibatkan perubahanya input secara fungsional. Proses pendidikan selalu ada input (masukan) berupa peserta didik kemudian dilakukan proses atau pembelajaran yang akhirnya menghasilkan output (keluaran) berupa lulusan yang memeroleh hasil belajar yang diinginkan. Purwanto (2014:3) menyatakan bahwa hasil belajar merupakan suatu hasil yang dicapai dari proses belajar mengajar sesuai dengan tujuan pendidikan. Hasil belajar diukur untuk mengetahui pencapaian tujuan pendidikan sehingga hasil belajar harus sesuai dengan tujuan pendidikan. Lebih lanjut Suprijono (2012:5) mengungkapkan bahwa hasil belajar adalah suatu pola-pola perbuatan, nilai-nilai, pengertian-pengertian, sikap-sikap, apersepsi dan keterampilan. Hasil belajar juga dapat didefinisikan sebagai perbuatan perilaku secara keseluruhan bukan hanya salah satu aspek potensi kemanusiaan saja. Hasil belajar siswa adalah kemampuan yang diperoleh anak setelah melalui kegiatan belajar. Karena belajar itu sendiri merupakan suatu proses dari seseorang yang berusaha untuk memperoleh suatu bentuk perubahan prilaku yang relatif menetap.

Menurut Jihad dan Haris (2012:14) menyatakan hasil belajar adalah kemampuan yang diperoleh siswa setelah melalui kegiatan belajar. Susanto (2013:5) menyatakan hasil belajar yaitu perubahan-perubahan yang terjadi pada diri siswa, baik yang menyangkut aspek kognitif, afektif, dan psikomotor sebagai hasil dari kegiatan belajar. Sudjana (2013:22) menyatakan hasil belajar adalah kemampuan-kemampuan yang dimiliki siswa setelah ia menerima pengalaman belajarnya.

Hasil belajar menurut Winkel (1996) dalam Purwanto (2014: 45) adalah perubahan yang mengakibatkan manusia berubah dalam sikap dan tingkah lakunya. Rifa'i dan Anni (2012: 69) berpendapat bahwa "hasil belajar merupakan perubahan perilaku yang diperoleh siswa setelah mengalami kegiatan belajar". Nawawi dalam Susanto (2013: 5) menyatakan bahwa "hasil belajar dapat diartikan sebagai tingkat keberhasilan siswa dalam memelajari materi pelajararan di sekolah yang dinyatakan dalam skor yang diperoleh dari hasil tes mengenal jumlah materi pelajaran tertentu". Sudjana (2011:22) menyatakan bahwa "hasil belajar adalah kemampuan-kemampuan yang dimiliki siswa setelah ia menerima pengalaman belajarnya". Pendapat lain oleh Karwati dan Priansa (2014: 216) mendefinisikan "hasil belajar adalah sesuatu yang dicapai atau diperoleh siswa berkat adanya usaha atau pikiran yang dinyatakan dalam bentuk penguasaan, pengetahuan, dan kecakapan dasar yang terdapat dalam berbagai aspek kehidupan sehingga nampak perubahan tingkah laku pada diri individu". Hasil belajar siswa akan tampak pada setiap perubahan pada aspek-aspek tertentu (Hamalik, 2012: 30). Aspek-aspek tersebut adalah: pengetahuan, pengertian, kebiasaan, keterampilan, apresiasi, emosional, pengaruh sosial, jasmani, budi pekerti, dan sikap.

Benyamin S Bloom dalam Purwanto (2014:50) membagi dan menyusun secara hirarkis tingkat hasil belajar kognitif mulai dari yang paling rendah dan sederhana yaitu hafalan sampai yang paling tinggi yaitu evaluasi. Makin tiggi tingkat maka makin kompleks dan penguasaan suatu tingkatmempersyaratkan penguasaan tingkat 9 sebelumnya. Enam tingkat itu adalah hafalan $(\mathrm{C} 1)$, pemahaman $(\mathrm{C} 2)$, penerapan $(\mathrm{C} 3)$, analisis (C4), sintesis (C5) dan evaluasi (C6).

Macam-macam hasil belajar menurut Susanto (2013:6) meliputi pemahaman konsep (aspek kognitif), keterampilan proses (aspek psikomotor), dan sikap siswa (aspek afektif). Pemahaman dapat diartikan sebagai kemampuan untuk menyerap arti dari materi atau bahan yang dipelajari, sedangkan konsep merupakan sesuatu yang tergambar dalam pikiran, suatu pemikiran, gagasan, atau suatu pengertian. Jadi, pemahaman konsep adalah seberapa besar siswa mampu menerima, menyerap, dan memahami pelajaran yang diberikan guru atau seberapa jauh siswa mengerti tentang gagasan atau suatu pengertian berupa hasil penelitian atau observasi langsung yang telah dilakukan. Orang yang telah memiliki konsep, berarti orang tersebut telah memiliki pemahaman yang jelas tentang sesuatu konsep atau citra. Untuk mengukur hasil belajar siswa yang berupa pemahaman konsep, guru dapat melakukan evaluasi produk. Evaluasi produk dapat dilaksanakan dengan mengadakan berbagai macam tes, baik secara lisan maupun tertulis. Dalam pembelajaran di SMA, umumnya tes diselenggarakan dalam berbagai bentuk ulangan, baik ulangan harian, ulangan semesteran, maupun ulangan umum. Dalam penelitian ini hasil belajar yang dimaksud mengacu pada hasil belajar kognitif siswa dalam proses pembelajaranya. 
Indratano, Pengaruh Kebiasaan Belajar Daring terhadap Hasil Belajar Kognitif Siswa pada Mata Pelajaran Bahasa Indonesia Kelas XII IPA di SMA N Kerinci

\title{
METODE PENELITIAN
}

Peneliti dalam penelitian ini menggunakan metode penelitian kuantitatif dengan pendekatan asosiatif. Hal ini dapat terlihat dari rancangan penelitian yang dapat digambarkan sebagai berikut:

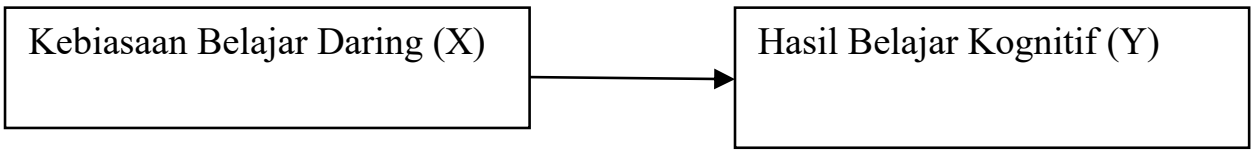

\section{Gambar 1 \\ Rancangan Penelitian}

Adapun yang dijadikan populasi dalam penelitian ini adalah siswa kelas XII IPA di SMA Negeri 7 Kerinci. Populasi menurut Arikunto (2013:70) adalah sebagai keseluruhan subjek penelitian atau suatu wilayah yang generalisasi yang terdiri atas objek/subjek yang mempunyai kuantitas dan karakteristik tertentu yang diterapkan oleh peneliti untuk dipelajari dan kemudian ditarik kesimpulannya. Pada tabel berikut dapat dilihat populasi dalam penelitian ini:

Tabel 1

Populasi Penelitian

\begin{tabular}{|l|l|c|}
\hline No & \multicolumn{1}{|c|}{ Siswa Kelas } & Jumlah \\
\hline 1 & XII IPA 1 & 28 \\
\hline 2 & XII IPA 2 & 27 \\
\hline 3 & XII IPA 3 & 32 \\
\hline & Jumlah & $\mathbf{9 7}$ \\
\hline
\end{tabular}

Dari tabel diatas dapat diketahui bahwa jumlah populasi dalam penelitian ini sebanyak 97siswa. Populasi tersebut diambil beberapa sampel melalui teknik pengambilan sampel dengan menggunakan simple random sampling, dimana pengambilan sampel tiap kelas ditentukan seimbang atau sebanding dengan banyaknya subjek dari setiap kelas. Untuk menghitung sampel penelitian dari populasi tersebut, peneliti menggunakan pedoman penentuan sampel yang dikembangkan dari Isaac dan Michael dalam Sugiyono (2016:71) dengan taraf tingkat kesalahan 5\% sehingga sampel dalam penelitian ini sebanyak 32 siswa.

Variable dalam penelitian ini yaitu kebiasaan belajar daring (X1) sebagai variable bebas dan hasil belajar (Y) sebagai variable terikat. Instrumen penelitian yang digunakan dalam penelitian ini berupa angket tertutup yaitu pernyataan atau pertanyaan yang diajukan pada responen untuk memilih alternative jawaban yang telah disediakan untuk mengukur kebiasaan belajar daring (X1). Instrumen angket kebiasaan belajar daring (X) penelitian ini menggunakan skala likert untuk mengukurnya, dan hasil belajar kognitif beardasarkan hasil belajar ujian berupa pengetahuan pembelajaran pada pembelajaran bahasa Indonesia. Selanjutnya dilakukan uji validitas dan reliabilitas dari angket tersebut untuk mengumpulkan data. Setelah data terkumpul dilakukan uji analisis deskriptif, uji normalitas, uji homogenitas, uji hipotesis dengan menggunakan uji regresi sederhana dan uji t. Dalam perhitungan data dalam penelitian ini menggunakan bantuan SPSS for Windows versi 25 (Gozali, 2018:34)

\section{HASIL DAN PEMBAHASAN}

Dari hasil data yang telah ditabulasikan dilakukan uji validitas dan reliabilitas data, dimana hasil uji tersebut item pernyataan sebanyak 15 item yang disebarkan melalui angket tentang variable kebiasaan belajar daring dapat dilihat pada tabel berikut:

\author{
Tabel 2 \\ Uji Validitas \\ Item-Total Statistics
}


Indratano, Pengaruh Kebiasaan Belajar Daring terhadap Hasil Belajar Kognitif Siswa pada Mata Pelajaran Bahasa Indonesia Kelas XII IPA di SMA N Kerinci

\begin{tabular}{|l|r|r|r|r|}
\hline & $\begin{array}{c}\text { Scale Mean } \\
\text { if Item } \\
\text { Deleted }\end{array}$ & $\begin{array}{c}\text { Scale Variance if } \\
\text { Item Deleted }\end{array}$ & $\begin{array}{c}\text { Corrected } \\
\text { Item-Total } \\
\text { Correlation }\end{array}$ & $\begin{array}{c}\text { Cronbach's } \\
\text { Alpha if Item } \\
\text { Deleted }\end{array}$ \\
\hline Item1 & 63.56 & 30.706 & .553 & .895 \\
Item2 & 63.59 & 29.604 & .595 & .894 \\
Item3 & 63.72 & 31.370 & .358 & .902 \\
Item4 & 63.56 & 29.609 & .768 & .889 \\
Item5 & 63.59 & 29.604 & .595 & .894 \\
Item6 & 63.59 & 28.765 & .813 & .886 \\
Item7 & 63.59 & 29.604 & .595 & .894 \\
Item8 & 63.72 & 31.370 & .358 & .902 \\
Item9 & 63.59 & 28.765 & .813 & .886 \\
Item10 & 63.59 & 29.604 & .595 & .894 \\
Item11 & 63.78 & 29.015 & .537 & .897 \\
Item12 & 63.78 & 29.015 & .537 & .897 \\
Item13 & 63.59 & 28.765 & .813 & .886 \\
Item14 & 63.59 & 29.604 & .595 & .894 \\
Item15 & 63.75 & 31.548 & .351 & .903 \\
\hline
\end{tabular}

Dari tabel di atas dapat diketahui bahwa hasil uji validitas variable kebiasaan belajar daring dinyatakan valid karena hasil $r$ prhitungan $>r$ tabel $(0,349)$ dengan sampel 32 siswa. Sedangkan untuk hasil uji reliabilitas dapat diketahui pada tabel berikut:

Tabel 3

Uji Reliabilitas

Reliability Statistics

\begin{tabular}{|r|r|}
\hline $\begin{array}{c}\text { Cronbach's } \\
\text { Alpha }\end{array}$ & N of Items \\
\hline .900 & 15 \\
\hline
\end{tabular}

Tabel di atas dapat diketahui bahwa uji reliabilitas dari variable kebiasaan belajar daring (X) dinyatakan reliable karena $r$ hitung uji reliabilitas sebesar $0.900>r$ tabel $(0,349)$ dengan sampel 32 siswa. Setalah dilakukan uji tersebut langkah selanjutnya melakukan perhitungan uji analisis deskriptif yang dapat diketahui hasilnya sebagai berikut:

\section{Tabel 4}

Uji Analisis Deskriptif

Descriptive Statistics

\begin{tabular}{|l|r|r|r|r|r|}
\hline & $\mathrm{N}$ & \multicolumn{1}{|c|}{ Mean } & \multicolumn{1}{c|}{$\begin{array}{c}\text { Std. } \\
\text { Deviation }\end{array}$} & $\begin{array}{c}\text { Minimu } \\
\mathrm{m}\end{array}$ & $\begin{array}{c}\text { Maximu } \\
\mathrm{m}\end{array}$ \\
\hline $\begin{array}{l}\text { Kebiasaan Belajar Daring } \\
\text { (X) }\end{array}$ & 32 & 68.19 & 5.828 & 54 & 75 \\
Hasil Belajar Kognitif (Y) & 32 & 85.16 & 4.266 & 77 & 95 \\
\hline
\end{tabular}


Indratano, Pengaruh Kebiasaan Belajar Daring terhadap Hasil Belajar Kognitif Siswa pada Mata Pelajaran Bahasa Indonesia Kelas XII IPA di SMA N Kerinci

Deskriptif statistic di atas, dapat dilihat bahwa rata-rata dari masing masing variable bebas kebiasaan belajar daring (X) sebesar 68,19 dan variable terikat hasil beajar kognitif (Y) sebesar 85,16 dengan nilai minimum untuk kebiasaan belajar daring (X) sebesar 54 dan hasil beajar kognitif (Y) sebesar 77. Sedangkan nilai maksimum yang diperoleh kebiasaan belajar daring (X) sebesar 75 dan hasil beajar kognitif (Y) sebesar 95 dengan standar deviasi variable kebiasaan belajar daring (X) sebesar 5.828 dan hasil beajar kognitif (Y) sebesar 4.266. Adapun perhitungan data yang dilakukan selanjutnya adalah untuk menguji data yang diperoleh dari penelitian tersebut berdistribusi normal atau tidak dapat dilihat pada tabel berikut:

\section{Tabel 5 \\ Uji Normalitas}

One-Sample Kolmogorov-Smirnov Test

\begin{tabular}{|ll|r|r|}
\hline & & \multicolumn{1}{c|}{ X } & \multicolumn{1}{c|}{$\mathrm{Y}$} \\
\hline $\mathrm{N}$ & & 32 & 32 \\
Normal Parameters ${ }^{\mathrm{a}, \mathrm{b}}$ & Mean & 68.19 & 85.16 \\
& Std. & 5.828 & 4.266 \\
& Deviation & .122 & .110 \\
Most Extreme & Absolute & .121 & .105 \\
Differences & Positive & -.122 & -.110 \\
& Negative & .122 & .110 \\
Test Statistic & & $.200^{\mathrm{c}, \mathrm{d}}$ & $.200^{\mathrm{c}, \mathrm{d}}$ \\
\hline Asymp. Sig. (2-tailed) & & \multicolumn{2}{|c}{} \\
\hline
\end{tabular}

a. Test distribution is Normal.

b. Calculated from data.

c. Lilliefors Significance Correction.

d. This is a lower bound of the true significance.

Data yang diperoleh dapat dikatakan normal atau tidak bisa dilihat dari Asymp. Sig. (2-tailed). Pada tabel di atas dapat diketahui bahwa Asymp. Sig. (2-tailed) dari variable bebas kebiasaan belajar daring (X) sebesar 0,200 > taraf signifikansi 5\% atau 0,05 maka dapat dikatakan data tersebut adalah normal, demikian juga untuk data hasil belajar kognitif (Y) dimana Asymp. Sig. (2-tailed) diperoleh sebesar 0,2000,200 > taraf signifikansi 5\% atau 0,05 maka dapat dikatakan data tersebut juga adalah normal. Setelah data dari masingmasing variable tersebut dikatakan normal maka langkah selanjutnya adalah menghitung homogenitas data untuk mengetahui variasi kelompok populasi homogeny atau tidak, uji homogeny yang dilakukan dalam penelitian ini dengan menggunakan uji Levene Statistic yang dapat dilihat pada tabel berikut:

\section{Tabel 6}

\section{Uji Homogenitas}

Test of Homogeneity of Variances

\begin{tabular}{|c|c|c|c|}
\hline $\begin{array}{l}\text { Levene } \\
\text { Statistic }\end{array}$ & df1 & $\mathrm{df} 2$ & Sig. \\
\hline 1.596 & 6 & 19 & .203 \\
\hline
\end{tabular}

Dari tabel di atas dapat diketahui bahwa uji Levene Statistic nilai signifikansinya $>0,05$ (taraf kepercayaan $95 \%$ ), maka dapat disimpulkan bahwa data yang digunakan adalah homogen. Setelah data dari variabel tersebut normal, maka dilakukanlah uji regresi linier sederhana untuk mengetahui sumbangsih 
Indratano, Pengaruh Kebiasaan Belajar Daring terhadap Hasil Belajar Kognitif Siswa pada Mata Pelajaran Bahasa Indonesia Kelas XII IPA di SMA N Kerinci

variabel bebas dengan variabel terikat yang dapat dilihat dari hasil perhitungan koefesien determinasi (R), dimana hasilnya dapat dilihat pada tabel berikut:

\section{Tabel 7}

Sumbangsih Koefesien Diterminasi

\begin{tabular}{|l|c|r|r|r|}
\hline \multicolumn{7}{|c|}{ Model Summary } \\
\hline Model & $\mathrm{R}$ & R Square & $\begin{array}{c}\text { Adjusted R } \\
\text { Square }\end{array}$ & $\begin{array}{c}\text { Std. Error of } \\
\text { the Estimate }\end{array}$ \\
\hline 1 & $.510^{\mathrm{a}}$ & .260 & .133 & 4.331 \\
\hline
\end{tabular}

a. Predictors: (Constant), $\mathrm{X}$

Berdasarkan tabel 7 di atas menunjukkan Nilai R sebesar 0,510 (51\%) dapat diintepretasikan bahwa variabel kebiasaan belajar daring (X) menerangkan variasi variabel hasil belajar kognitif (Y) pada mata pelajaran bahasa Indonesia siswa kelas XII IPA di SMA Negeri 7 Kerinci sebesar 51\% dan sisanya diperngaruhi variabel independen lainnya sebesar $49 \%$. Untuk mengetahui adanya pengaruh atau tidak antara variable kebiasaan belajar daring (X) dengan hasil belajar kognitif (Y) mata pelajaran bahasa Indonesia siswa kelas XII IPA di SMA Negeri 7 Kerinci dapat menggunakan uji t yang hasilnya dapat dilihat pada tabel berikut:

\section{Tabel 8}

\section{Regresi Linier Sederhana dan Uji t}

\section{Coefficients $^{\mathrm{a}}$}

\begin{tabular}{|c|c|c|c|c|c|c|}
\hline \multirow{2}{*}{\multicolumn{2}{|c|}{ Model }} & \multicolumn{2}{|c|}{$\begin{array}{c}\text { Unstandardized } \\
\text { Coefficients }\end{array}$} & \multirow{2}{*}{$\begin{array}{c}\begin{array}{c}\text { Standardized } \\
\text { Coefficients }\end{array} \\
\text { Beta } \\
\end{array}$} & \multirow[b]{2}{*}{$\mathrm{t}$} & \multirow[b]{2}{*}{ Sig. } \\
\hline & & B & Std. Error & & & \\
\hline \multirow[t]{2}{*}{1} & (Constant) & 87.678 & 9.134 & & 9.599 & .000 \\
\hline & $\begin{array}{l}\text { KB } \\
\text { Daring }\end{array}$ & 2.037 & 2.133 & .051 & 2.277 & .040 \\
\hline
\end{tabular}

a. Dependent Variable: Y

Koefisien $\beta$ merupakan bentuk sebuah persamaan regresi linier sederhana yang dapat dihasilkan sebagai berikut: $\mathrm{Y}=87.678+2.037 \mathrm{X}+\mathrm{e}$. Dari persamaan diatas maka dapat dijadikan acuan untuk diintepretasikan sebagai berikut:

1. Koefisien Konstanta bernilai positif artinya bahwa ketika kebiasaan belajar daring tidak memperhatikan hasil belajar kognitif siswa kelas XII IPA di SMA Negeri 7 Kerinci akan tetap memiliki hasil belajar kognitif.

2. Koefisien kebiasaan belajar daring bernilai positif artinya setiap kenaikan kebiasaan belajar daring yang dimiliki siswa kelas XII IPA di SMA Negeri 7 Kerinci meningkat, akan disertai dengan peningkatan hasil belajar kognitif siswa. Sedangkan setiap penurunan kebiasaan belajar daring yang dimiliki siswa kelas XII IPA di SMA Negeri 7 menurun, akan disertai penurunan hasil belajar kognitif siswa.

Pengujian Signifikan Uji t bertujuan untuk mengetahui pengaruh variabel bebas kebiasaan belajar daring (X) dengan hasil belajar kognitif (Y). Nilai t hitung yang dihasilkan pada variabel kebiasaan belajar daring (X) adalah 2,277 dengan sig 0,040. Hasil tersebut mengindikasikan bahwa variabel kebiasaan belajar daring (X) memiliki pengaruh dengan hasil belajar kognitif (Y) yang dimilki siswa kelas XII IPA di SMA Negeri 7 Kerinci. Hal ini dikarenakan hasil perhitungan tersebut memiliki nilai t hitung sebesar 2,277 >t tabel sebesar 1,695 dengan taraf signifikansi sebesar 0,040 lebih kecil daripada 0,05 artinya variabel kebiasaan belajar daring (X) mempunyai pengaruh dengan hasil belajar kognitif (Y). 
Indratano, Pengaruh Kebiasaan Belajar Daring terhadap Hasil Belajar Kognitif Siswa pada Mata Pelajaran Bahasa Indonesia Kelas XII IPA di SMA N Kerinci

Hasil dari uji t yang dapat dilihat pada tabel 8 diketahui bahwa nilai t hitung untuk variabel kebiasaan belajar daring (X) sebesar 2,277 dengan taraf nilai Sig =0,040. Hasil perhitungan tersebut dapat ditarik suatu hipotesis diterima atau ditolak yaitu dengan melihat nilai t dan taraf nilai signifikansinya. Adapun hipotesis yang diajukan dalam penelitian ini adalah sebagai berikut:

$\mathrm{HO}$ : tidak ada pengaruh kebiasaan belajar daring (X) dengan hasil belajar kognitif (Y)

H1 : ada pengaruh kebiasaan belajar daring (X) dengan hasil belajar kognitif (Y)

Ketentuan dari hipotesis penelitian ini dapat diterima atau ditolak jika nilai $\mathrm{t}$ hitung $>\mathrm{t}$ tabel dan taraf nilai Sig $<0,05$, maka H0 ditolak. Sedangkan jika nilai t hitung $<\mathrm{t}$ tabel dan taraf nilai Sig $>0,05$, maka H0 diterima. Untuk melihat nilai $\mathrm{t}$ tabel, maka terlebih dahulu harus menetapkan derajat kebebasan (dk). Keseluruhan sampel yang diteliti $(\mathrm{N})$ dalam penelitian ini ditentukan dengan rumus $\mathrm{dk}=\mathrm{n}-1$. Dalam penelitian ini, jumlah prediktor ada 1 yaitu kebiasaan belajar daring $(\mathrm{X})$ dan total sampel yang digunakan adalah 32 siswa kelas XII IPA SMA Negeri 7 Kerinci maka $d k=32-1=31$ pada taraf signifikansi 5\%, maka diperoleh nilai t tabel $=1,695$. Dikarenakan perolehan nilai t hitung variabel kebiasaan belajar daring (X) sebesar 2,277 $>\mathrm{t}$ tabel $=1,695$ dan taraf nilai Sig $=0,040<0,05$, sehingga dapat disimpulkan bahwa $\mathrm{H} 0$ ditolak, artinya ada pengaruh kebiasaan belajar daring (X) dengan hasil belajar kognitif siswa kelas XII IPA SMA Negeri 7 Kerinci. Oleh karena itu hasil belajar kognitif siswa kelas XII IPA SMA Negeri 7 Kerinci memiliki pengaruh dengan kebiasaan belajar daring (X) secara langsung. Artinya jika kebiasaan belajar daring (X) siswa kelas XII IPA SMA Negeri 7 Kerinci baik maka hasil belajar kognitif siswa XII IPA SMA Negeri 7 Kerinci juga baik, dan sebaliknya jika kebiasaan belajar daring (X) siswa kelas XII IPA SMA Negeri 7 kurang baik maka hasil belajar kognitif siswa kelas XII IPA SMA Negeri 7 Kerinci juga tidak baik

Kebiasaan belajar merupakan salah satu kunci sukses dalam mencapai hasil belajar siswa, seperti yang diungkapkan Galih (2012:5) bahwa apabila seseorang ingin berhasil dalam belajarnya hendaknya orang tersebut memiliki sikap dan cara belajar yang baik. Dimana, cara-cara belajar yang baik itu disebut juga sebagai dengan kebiasaan belajar, terlebih lagi dalam kondisi pandemic covid 19 ini kebiasaan belajar berubah total menjadi kebiasaan belajar secara daring sehingga kebiasaan belajar secara daring bisa tercapai dengan baik itu ditentukan dengan kebiasaan belajarnya. Hasil penelitian ini sejalan dengan hasil penelitian yang dilakukan oleh Rahayu (2015) dengan judul "Pengaruh Kebiasaan Belajar Terhadap Hasil Belajar Matematika", dimana penelitian oleh Rahayu menunjukan bahwa adanya pengaruh kebiasaan belajar secara signifikan terhadap hasil belajar matematika. Secara perhitungan yang dilakukan pengaruh yang diberikan kebiasaan belajar terhadap hasil belajar sebesar 32,3\% sisanya dipengaruhi variable lain sebesar 67,7\%

Kebiasaan belajar siswa kelas XII IPA SMA Negeri 7 Kerinci akan menentukan kebiasaan belajarnya sendiri. Apabila cara belajar siswa kelas XII IPA SMA Negeri 7 Kerinci baik, maka akan tercipta kebiasaan belajar yang baik dan juga dapat meningkatkan hasil belajar siswa itu sendiri. Kebiasaan belajar yang baik juga akan menolong siswa kelas XII IPA SMA Negeri 7 Kerinci untuk memahami pelajarannya, menguasai materi pembelajaran sehingga dapat memperoleh hasil belajar yang optimal. Sedangkan kebiasaan belajar yang tidak baik akan mempersulit siswa kelas XII IPA SMA Negeri 7 Kerinci untuk memahami pelajarannya dan menghambat kemajuan pembelajaran serta memperoleh hasil belajar yang tidak optimal dalam proses pembelajarannya. Dalam proses pembelajaran, belajar secara efisien juga perlu dibudayakan dalam diri siswa agar tercipta kebiasaan belajar yang baik. Seperti yang diungkapkan Syah (2009:134) bahwa belajar secara efisien akan menciptakan kebiasaan belajar siswa, dimana terdapat dua macam efisiensi belajar dalam diri siswadiantaranya sebagai berikut:

1) Efisiensi usaha belajar, suatu kegiatan belajar dapat dikatakan efisien apabila hasil belajar yang diinginkan dapat dicapai dengan usaha. Usaha dalam hal ini yaitu dengan membiasakan belajar dengan baik dengan membuat jadwal belajar secara teratur, meluangkan tenaga dan pikiran, peralatan belajar yang diperlukan, dan lain-lain.

2) Efisiensi hasil belajar, sebuah kegiatan belajar dapat dikatakan efisien apabila dengan usaha belajar tertentu memberikan hasil belajar tinggi. Sehingga dengan usaha membiasakan belajar secara teratur maka hasil belajar yang diinginkan dapat tercapai dengan maksimal. Jadi, dapat 
Indratano, Pengaruh Kebiasaan Belajar Daring terhadap Hasil Belajar Kognitif Siswa pada Mata Pelajaran Bahasa Indonesia Kelas XII IPA di SMA N Kerinci

disimpulkan bahwa kebiasaan belajar ada pengaruhnya dengan hasil belajar karena dengan kebiasaan belajar yang baik maka akan mendapatkan hasil belajar yang baik pula.

\section{SIMPULAN}

Berdasarkan hasil penelitian yang telah dilakukan pada siswa kelas XII IPA SMA Negeri 7 Kerinci diperoleh hasil dan pembahasan yang dapat dipetik menjadi suatu kesimpulan bahwa adanya pengaruh yang signifikan antara kebiasaan belajar daring dengan hasil belajar kognitif siswa kelas XII IPA SMA Negeri 7 Kerinci pada mata pelajaran bahasa Indonesia. Hal ini dapat dilihat pembuktianya dari hasil olahan dengan menggunakan rumus uji $t$ dengan taraf signifikansi 0,05. Dimana, terdapat pengaruh kebiasaan belajar daring terhadap hasil belajar kognitif siswa kelas XII IPA SMA Negeri 7 Kerinci ditandai dengan nilai $t$ hitung $>\mathrm{t}$ tabel dan siginifikansi $0,040<0,05$. Besarnya pengaruh kebiasaan belajar daring terhadap hasil belajar bahasa Indonesia siswa kelas XII IPA SMA Negeri 7 Kerinci tergolong kuat yaitu sejumlah $51 \%$ dengan sisa 49\% dipengaruhi oleh faktor lain di luar penelitian.

\section{DAFTAR PUSTAKA}

Ahmad, Susanto. 2013. Teori Belajar dan Pembelajaran di Sekolah Dasar. Jakarta: Kencana Prenada Media Group.

Ardiansyah, Asrori. 2012. Kebiasaan Belajar. http://kabar-pendidikan.blogspot.com. (2 juni 2012)

Arikunto, Suharsimi. 2013. Prosedur Penelitian: Suatu Pendekatan Praktik. Jakarta: Rineka Cipata

Aunurrahman. 2013. Belajar dan Pembelajaran. Bandung: Alfabeta

Djaali. 2014. Psikologi Pendidikan. Jakarta: Bumi Aksara

Galih, Ariwaseso. 2012. Minat Dan Kebiasaan Belajar Terhadap Prestasi Belajar Mata Pelajaran Akuntansi Siswa Kelas Xi Ips Sma Negeri 1 Pataianrowo Nganjuk. Fakultas Ekonomi: Universitas Negeri Surabaya

Gie, The Liang. 1995. Cara Belajar yang Efisien Jilid II Edisi keempat (diperbaharui). Yogyakarta: Liberty. Gilmer, V. H. Industrial Psychology. 1996. USA: McGraw Hill Book Company Inc.

Ghozali, Imam. 2018. Aplikasi Analisis Multivariate dengan Program IBM SPSS 25. Semarang: Badan Penerbit Universitas Diponegoro:

Jihad, Asep dan Haris, Abdul. 2012. Evaluasi Pembelajaran. Jakarta: Multi Presssindo

Purwanto. 2014. Evaluasi Hasil belajar. Yogyakarta: Pustaka Pelajar

Rahayu, Mardiyatun Mugi. 2015. Pengaruh Kebiasaan Belajar Terhadap Hasil Belajar Matematika. Journal of Elementary Education 4 (1) (2015) ISSN 2252-9047

Rifa'i, A dan Anni, C.T. 2012. Psikologi Pendidikan. Semarang: UPT UNNES Press

Sudjana, Nana. 2011. Penilaian Hasil Proses Belajar Mengajar. Bandung: PT Remaja Rosdakarya. . 2013. Dasar-Dasar Proses Belajar Mengajar. Bandung: Sinar Baru Algensindo.

Sugiyono. 2016. Metode Penelitian Kuantitatif, Kualitatif dan R\&D. Bandung: PT Alfabet Slameto. 2015. Belajar dan Faktor-faktor yang Memengaruhinya. Jakarta: Rineka Cipta Suprijono. Agus. 2012. Cooperative Learning: Teori dan Aplikasi Paikem. Yogyakrta: Pustaka Pelajar. Susanto, Ahmad. 2013. Teori Belajar dan Pembelajaran di Sekolah Dasar. Jakarta: Kencana Prenadamedia Group

Syah, Muhibbin. 2009. Psikologi Belajar. Jakarta : PT Raja Grafindo Persada. 
Indratano, Pengaruh Kebiasaan Belajar Daring terhadap Hasil Belajar Kognitif Siswa pada Mata Pelajaran Bahasa Indonesia Kelas XII IPA di SMA N Kerinci 